\title{
Proteins and glycosaminoglycans in the intercellular matrix of the human cumulus-oophorus and their effect on conversion of proacrosin to acrosin
}

\author{
J. Drahorád ${ }^{1}$, J. Tesařík ${ }^{2}$, D. Čechová ${ }^{1}$ and V. Vilím ${ }^{3}$ \\ ${ }^{1}$ Institute of Molecular Genetics, Czechoslovak Academy of Sciences, Flemingovo nám. 2, \\ 16637 Praha 6, Czechoslovakia; ${ }^{2}$ Centre for Reproductive Medicine, Faculty of Medicine, \\ T. G. Masaryk University, 66233 Brno, Czechoslovakia; and ${ }^{3}$ Research Institute of Rheumatology, \\ Na Slupi 4, 12850 Praha 2, Czechoslovakia
}

\begin{abstract}
Summary. Human cumuli-oophori were cultured in vitro in the presence of radioactive protein and polysaccharide precursors. The time course of the cumulus cell secretion was traced by histoautoradiography. Matrix solubilization, and sodium dodecyl sulphate polyacrylamide gel electrophoresis and high-performance liquid chromatography showed that proteoglycan $\left(M_{\mathrm{r}}>1700000\right)$ was the main cumulus cell product that was prevailingly deposited in the cumulus intercellular matrix and partly released into the culture medium. It was capable of accelerating the conversion of proacrosin to acrosin and this activity was abolished by enzymatic removal of chondroitin sulphate, the predominant glycosaminoglycan of this proteoglycan fraction. None of the other fractions, including a proteoglycan of $M_{\mathrm{r}} 80000-90000$, containing heparan sulphate, accelerated the conversion of proacrosin to acrosin under the conditions used. The results suggest that chondroitin sulphate is the active component of the high- $M_{\mathrm{r}}$ proacrosin activator of the human cumulus-oophorus.
\end{abstract}

Keywords: fertilization; proacrosin activation; acrosin; cumulus-oophorus; man

\section{Introduction}

The cumulus-oophorus has a close relation to the oocyte during its preovulatory development and at fertilization. The uniqueness of this microenvironment is a result of the secretory activity of the cumulus cells and the stability of association of their proteinaceous secretions with the cumulus intercellular matrix, which consists predominantly of hyaluronic acid (Ball et al., 1982; Eppig, 1979). A relatively stable association of newly secreted glycoconjugates with the human cumulus intercellular material has been demonstrated (Tesařík \& Kopečný, 1986). In a preliminary investigation, we examined the interactions of the proteins secreted by cumulus cells with spermatozoa (Tesařík et al., 1988a). The present work is a continuation of those studies. The principal aim was to evaluate their effect on conversion of proacrosin to acrosin and to characterize further the active component(s).

\section{Materials and Methods}

Radioactive precursors. L- $\left[{ }^{3} \mathrm{H}\right]$ Leucine (Amersham International, UK, sp. act. $1470 \mathrm{GBq} / \mathrm{mmol}$ ) was used for labelling proteins and D- $\left[6 \cdot{ }^{3} \mathrm{H}\right]$ glucosamine hydrochloride (Amersham, sp. act. $940 \mathrm{GBq} / \mathrm{mmol}$ ) for labelling glycosaminoglycans for histoautoradiography. A mixture of $\mathrm{L}^{14} \mathrm{C}$-labelled amino acids and $\left[{ }^{35} \mathrm{~S}_{\mathrm{Na}} \mathrm{SO}_{4}\right.$ (Institute for Research Production and Application of Radioisotopes, Prague, Czechoslovakia, sp. act. $1.456 \mathrm{GBq} / \mathrm{ml}$ and $615.4 \mathrm{MBq} / \mathrm{ml}$, 
(a)

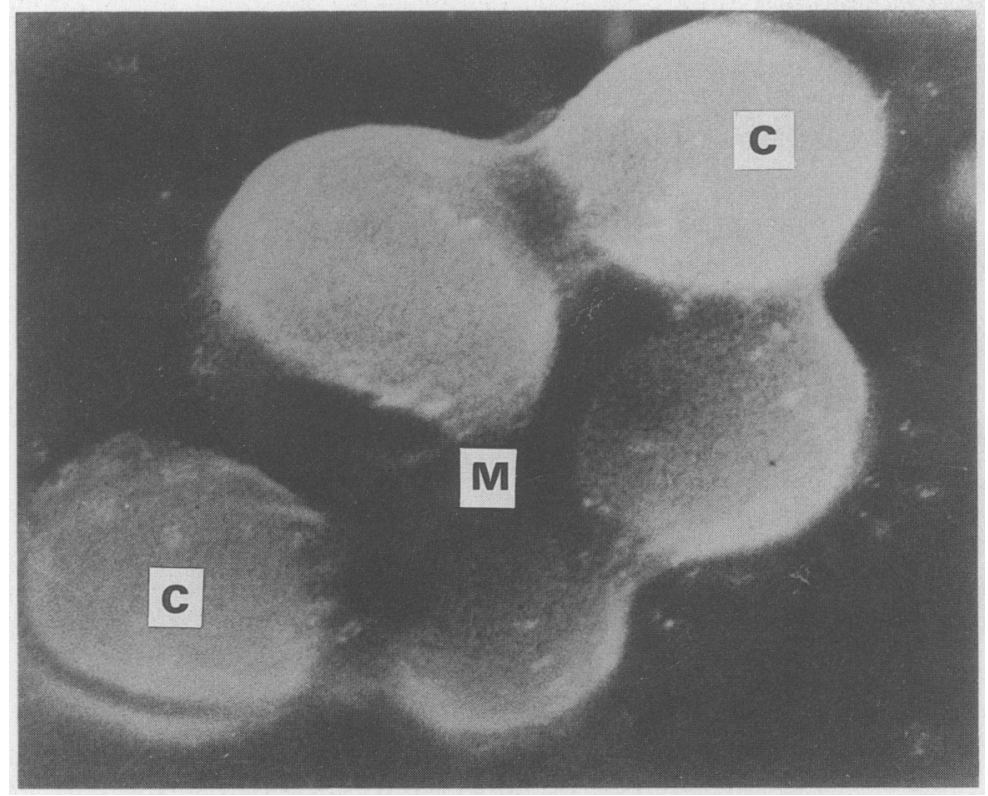

(b)

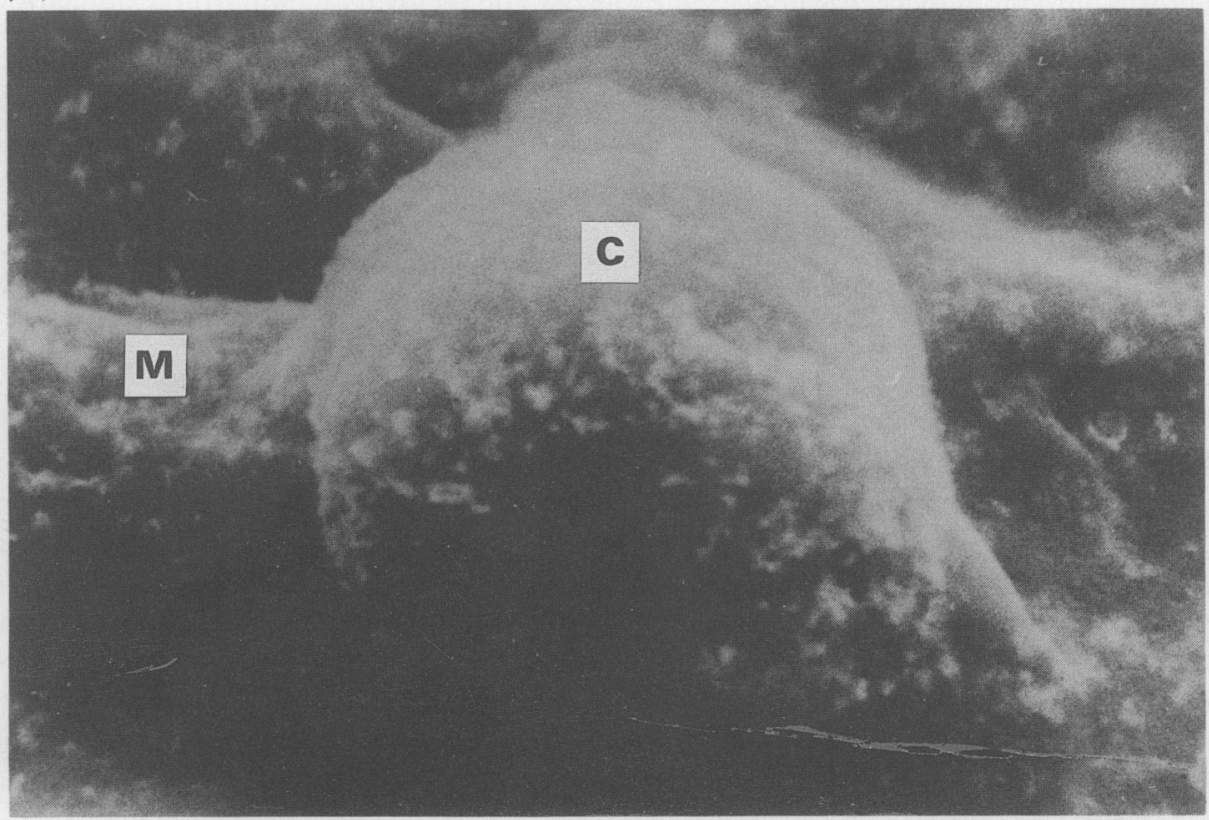

Fig. 1. (a) and (b).

respectively) and $\left[{ }^{14} \mathrm{C}\right] \mathrm{t}$-fucose (Amersham, sp. act. $2 \cdot 11 \mathrm{GBq} / \mathrm{mmol}$ ) were used for labelling of protein and glycosaminoglycan in biochemical experiments.

Sources and preparation of boar proacrosin and human sperm suspensions. Proacrosin was isolated from ejaculated boar spermatozoa; sperm collection and extraction and zymogen isolation has been described by Jonáková el al. (1990). Human semen samples were collected by masturbation from apparently healthy partners of women treated in an in-vitro fertilization programme. Tests for quality and preparation of sperm suspension have been described by Tesařik (1985). 
(c)

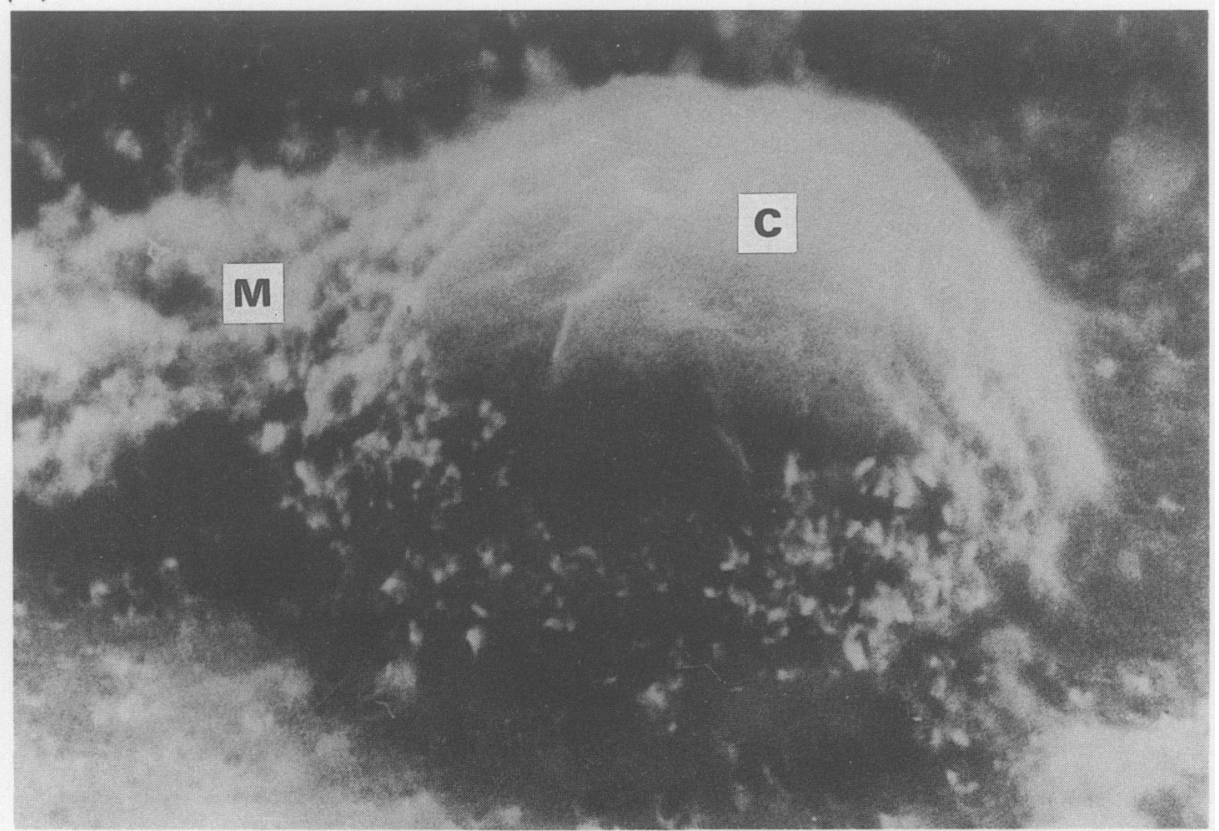

Fig. 1. (c).

Fig. 1. Scanning-electron-microscope autoradiographs of human cumuli-oophori spread on microscope slides: (a) part of a cumulus oophorus incubated with $\left[{ }^{3} \mathrm{H}\right]$ leucine for $30 \mathrm{~min}$ $(\times 8000)$; (b) a cumulus cell and adjacent cumulus intercellular matrix after incubation with $\left[{ }^{3} \mathrm{H}\right]$ leucine for $2 \mathrm{~h}$ or $(\mathrm{c})$ additional incubation for $6 \mathrm{~h}$ in radioactivity-free medium $(\times 15000)$. Light spots on cells $(C)$ and intercellular matrix $(M)$ represent radioactivity.

Cumulus recovery. Human cumuli- oophori were separated mechanically from 55 oocyte cumulus complexes from 26 women in an in-vitro fertilization programme. Ovaries were stimulated with $100 \mathrm{mg}$ clomiphene citrate (Gravosan, Spofa, Prague, Czechoslovakia) administered on Days 3-7 of the menstrual cycle followed by 6000 iu of human chorionic gonadotrophin (hCG; Praedyn, Spofa), applied when the diameter of the leading follicle had reached $18 \mathrm{~mm}$ (ultrasonic measurement). Follicles were aspirated under laparoscopic control 34-36 h later. The cumulus was cut off each oocyte-cumulus complex using a sharp hypodermic needle.

Labelling of proteins secreted by cumulus cells. Cumuli were incubated for $30-120 \mathrm{~min}$ in Ham's F10 culture medium (Flow Laboratories, Rockville, MD, USA) enriched with 30\% follicular fluid from the respective follicles and supplemented with radioactive precursor to $3.7 \mathrm{MBq} / \mathrm{ml}$. Details of the culture conditions have been reported by Tesařik et al. (1984). After the incorporation period, cumuli were thoroughly washed free of unincorporated radioactivity in fresh culture medium and cultured in $1 \mathrm{ml}$ medium for 6-8h. The cumuli were either processed for autoradiography or treated with hyaluronidase for biochemical analysis. Pooled medium was freeze-dried and used for sodium dodecyl sulphate polyacrylamide gel electrophoresis (SDS-PAGE).

Histoautoradiography. After incubation with tritiated precursors and a chase period in some experiments, the cumuli were spread on slides to obtain a thin layer of cumulus cells surrounded by intercellular material. The process was controlled under a dissecting microscope and care was taken to avoid superimposing intercellular matrix over the cells. The slides were air-dried and fixed for $12 \mathrm{~h}$ with a solution containing $4 \%$ paraformaldehyde and $1 \%$ cetylpyridinium chloride (Prolabo, Paris, France). Fixed slides were coated with a monolayer of Ilford L4 nuclear liquid emulsion and exposed for 1 month. Autoradiographs were developed in D19 and the slides were cut into $1 \mathrm{~cm}$ squares which were then coated with carbon and examined in a Tesla BS 300 scanning electron microscope.

Liquefaction of intercellular matrix. For intercellular-matrix examination by SDS-PAGE, cumuli were treated with $10 \mathrm{U}$ of bovine testicular hyaluronidase (Spofa, Prague, Czechoslovakia) in $1 \mathrm{ml}$ medium at $37^{\circ} \mathrm{C}$ for $30 \mathrm{~min}$. The basic proteinase inhibitor aprotinin (Antilysin, Spofa) and the SH-proteinase inhibitor 4-hydroxymercuribenzoic acid Na-sait (Serva Feinbiochemica, GMBH \& Co., Heidelberg, Germany) were added, each at $100 \mu \mathrm{g} / \mathrm{ml}$. Dissolution of the cumulus intercellular material was controlled under an inverted microscope. The digested intercellular material was separated from cumulus cells by centrifugation $(500 \mathrm{~g}$ for $15 \mathrm{~min}$ ). The supernatant was immediately frozen and freeze-dried. In all other experiments, intercellular matrix was liquefied by sperm action. Resuspended, actively 


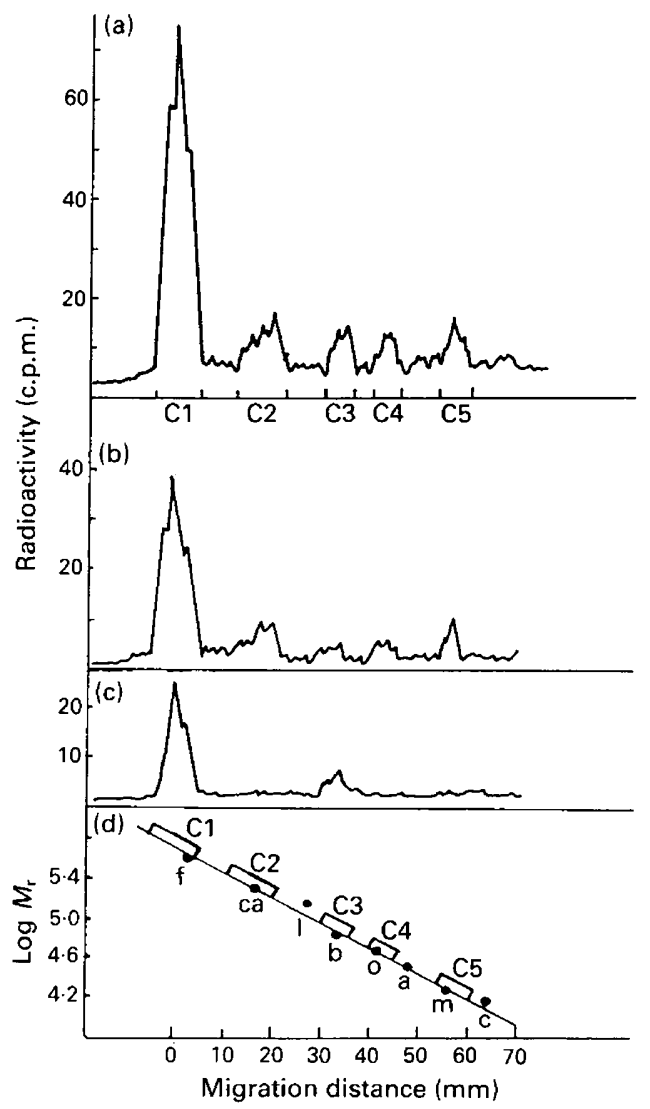

Fig. 2. Radioactivity distribution on electrophoretograms of hyaluronidase-digested human material: (a) cumuli-oophori intercellular matrix, (b) spent medium after cumulus culture with $\left[{ }^{14} \mathrm{C}\right]$ amino acid mixture and (c) matrix from cumuli prelabelled with $\left[{ }^{14} \mathrm{C}\right]$ fucose; (d) positions of the major protein groups, $\mathrm{C}_{1}-\mathrm{C}_{5}$, compared with standards (O): cytochrome $c$ (c), myoglobin $(\mathrm{m})$, anhydrase (a), ovalbumin (o), bovine serum albumin (b), lactate dehydrogenase (l), catalase (ca) and ferritin (f).

moving spermatozoa were added to cumulus mass in $1 \mathrm{ml}$ of culture medium. The number of spermatozoa per tube ranged between $1 \times 10^{5}$ and $1 \times 10^{6}$. After incubation for $30 \mathrm{~min}$ at $37^{\circ} \mathrm{C}$, cumulus cells and spermatozoa were sedimented by centrifugation $(1500 \mathrm{~g}$ for $15 \mathrm{~min}$ ). The supernatant containing solubilized components of cumulus matrix was decanted and checked under an inverted microscope for the absence of cumulus cells and spermatozoa. The material was stored at $-20^{\circ} \mathrm{C}$ until use.

Radioactivity measurement in liquid samples. Radioactive ${ }^{3} \mathrm{H},{ }^{14} \mathrm{C}$ and ${ }^{35} \mathrm{~S}$ in column effluent was determined on a Beckmann scintillation counter. Volumes of $5-1000 \mu l$ of specimens were pipetted into scintillation vessels and Bray scintillation solution was added to $5 \mathrm{ml}$.

Detection of proacrosin activator in column eluate. Purified proacrosin $(6 \mu \mathrm{g})$ in $0.05 \mathrm{ml} 0.001 \mathrm{M}-\mathrm{HCl}$ was added to a mixture of $2.4 \mathrm{ml} 0.1 \mathrm{M}$ Tris- $\mathrm{HCl}, 0.025 \mathrm{M}$ calcium chloride, $1 \mathrm{mg}$ D,L-benzoylarginine $p$-nitroanilide (BAPA), $0.1 \mathrm{ml}$ dimethylformamide, $\mathrm{pH} 7.8$, and $50 \mu \mathrm{l}$ of column eluate. After incubation at $25^{\circ} \mathrm{C}$ for $10 \mathrm{~min}$, the reaction was stopped by adding $0.5 \mathrm{ml} 30 \%$ acetic acid. Absorbance at $405 \mathrm{~nm}$ was measured against a control containing buffer instead of the tested sample.

Detection of proacrosin activator in liquid samples. Purified proacrosin $(6 \mu \mathrm{g})$ in $0.05 \mathrm{ml} 0.001 \mathrm{M}-\mathrm{HCl}$ was added to a mixture of $2.8 \mathrm{ml} 0.1 \mathrm{M}$ Tris- $\mathrm{HCl}, 0.025 \mathrm{M}$ calcium chloride, $1 \mathrm{mg}$ BAPA, $0.1 \mathrm{ml}$ dimethylformamide, $\mathrm{pH} 7 \cdot 8$, and $50 \mu \mathrm{l}$ of either pooled column fractions or medium after cumulus culture and intercellular matrix solubilization by coculture with spermatozoa. The change of absorbance at $405 \mathrm{~nm}$ was followed on a Pye Unicam 8630 kinetic spectrophotometer at $25^{\circ} \mathrm{C}$. The absorbancy change was compared with the acrosin activity assayed after $60 \mathrm{~min}$ of proacrosin autoactivation in $0.1 \mathrm{M}$ Tris- $\mathrm{HCl}, 0.025 \mathrm{M}$ calcium chloride, $\mathrm{pH} 7.8$, at $25^{\circ} \mathrm{C}$. The amounts of active enzyme were calculated from the slopes. Proacrosin and acrosin activities were expressed in international units (U). One 
proacrosin unit is the amount of proacrosin giving one acrosin unit after activation. One acrosin unit provides hydrolysis of $1 \mu \mathrm{mol}$ BAPA/min.

Digestion of glycosaminoglycans by chondroitinase $A B C$ or $A C$. Samples containing digest of intercellular matrix of cumulus-oophorus cells cultured in the presence of $\left[{ }^{35} \mathrm{~S}^{-N_{2}} \mathrm{SO}_{4}\right.$ were dialysed at $4{ }^{\circ} \mathrm{C}$ against a 300 -fold excess of $0.01 \mathrm{M}$ Tris- $\mathrm{HCl}$ buffer containing $0.15 \mathrm{M}-\mathrm{NaCl}$ and $0.02 \% \mathrm{NaN}_{3}, \mathrm{pH} \mathrm{7.4}$. Dialysis buffer was changed every $24 \mathrm{~h}$. After three changes, the buffer no longer contained measurable radioactivity. The dialysed digest was divided into three aliquots. Chondroitinase $\mathrm{ABC}$ or $\mathrm{AC}$ was added to a concentration of $0.5 \mathrm{mg} / \mathrm{ml}$ to the first and second aliquots, respectively; the third was used as an enzyme-free control. After overnight incubation at $37^{\circ} \mathrm{C}$, each sample was run down a TSK G-3000 SW column. Radioactivity was measured in separate fractions.

High-performance liquid chromatography. The high-pressure, inert Ti-system (LKB Instruments, Bromma, Sweden) was used. A glass column Glaspac TSK $0.8 \times 30 \mathrm{~cm}$, packed with TSK G-3000 SW (LKB), was equilibrated with $0.01 \mathrm{M}$ Tris- $\mathrm{HCl}$ buffer containing $0.15 \mathrm{M}-\mathrm{NaCl}$ and $0.02 \% \mathrm{NaN}_{3}, \mathrm{pH} 7.4$. The sample volume was $100 \mu$, the flow was $0.5 \mathrm{ml} / \mathrm{min}$. Chromatography in a stainless steel $4 \times 250 \mathrm{~mm}$ column filled with Separon Hema S-1000 (Laboratorni pristroje, Prague, Czechoslovakia) was performed in redistilled water at $1.0 \mathrm{ml} / \mathrm{min}$, the samples having been dialysed against redistilled water before application. The course of the chromatography was monitored by a Uvicord SD detector (LKB, Bromma, Sweden) at $226 \mathrm{~nm}$ wavelength. Fractions were collected at 1-min intervals.

SDS-PAGE. Samples of spent media after cumulus culture and of hyaluronidase-digested cumulus intercellular material were dissolved in SDS sample buffer (Laemmli, 1970). Proteins were separated under nonreducing conditions in $10 \%$ SDS polyacrylamide gels. Dried gels were scanned on a Berthold LB 2832 TLC linear radioactivity scanner. The position of radioactivity peaks was compared with molecular weight standards (Serva, Heidelberg, Germany) stained with Coomassie Blue.

\section{Results}

\section{Histoautoradiography}

Human cumuli-oophori showed active incorporation of $\left[{ }^{3} \mathrm{H}\right] l$ eucine into proteins being synthesized by their cells. After $30 \mathrm{~min}$ of incubation, silver grain formation was visible in cumulus cells and the intercellular matrix (Fig. 1a). After $2 \mathrm{~h}$ of incubation, cumulus cells and adjacent intercellular material were strongly labelled (Fig. 1b). If the incubation was followed by a chase for $6 \mathrm{~h}$ in fresh medium, the label was still present in the intercellular material, but only weak residual labelling remained on cumulus cells (Fig. 1c). A labelling pattern consistent with that described for $\left[{ }^{3} \mathrm{H}\right]$ leucine was observed in spread cumuli-oophori labelled with $\left[{ }^{3} \mathrm{H}\right] \mathrm{glucosamine}$ and chased for $6 \mathrm{~h}$ (data not shown).

\section{Labelled proteins and glycoproteins secreted by cumulus cells}

An electrophoretogram of medium containing solubilized matrix components after cumulus culture labelled with $\left[{ }^{14} \mathrm{C}\right]$ amino acids (Fig. 2a) showed numerous radioactivity peaks corresponding to one major protein family and four minor groups of proteins, and did not differ from that obtained from spent medium after cumulus culture treated in the same way (Fig. 2b). Proteins of the $\mathrm{C}_{1}$ group barely entered the gel. The $\mathrm{C}_{2}-\mathrm{C}_{5}$ protein groups were of $M_{\mathrm{r}}$ ranges $160000-350000$, $67000-110000,39000-59000$ and $15000-22000$, respectively.

Medium with matrix components labelled with $\left[{ }^{14} \mathrm{C}\right]$ fucose showed radioactivity in the $M_{\mathrm{r}}$ areas corresponding to $\mathrm{C}_{1}$ and $\mathrm{C}_{3}$ proteins (Fig. $2 \mathrm{c}$ ).

Three peaks of labelled proteins (Fig. 3a) were detected when the medium with matrix components labelled with $\left[{ }^{14} \mathrm{C}\right]$ amino acids was separated on a TSK G-3000 column. The first peak of radioactivity was eluted in the void volume (at $5.25-5.5 \mathrm{ml}$ ), the second at $8.0 \mathrm{ml}$ and the third at $12 \cdot 5 \mathrm{ml}$. Secretions labelled with both $\left[{ }^{14} \mathrm{C}\right]$ fucose and $\left[{ }^{35} \mathrm{~S}\right]$ sulphated groups were incorporated into glycosaminoglycans eluted from the TSK G-3000 column in two radioactive peaks at $5 \cdot 25-5.5 \mathrm{ml}$ and $8.0 \mathrm{ml}$. 

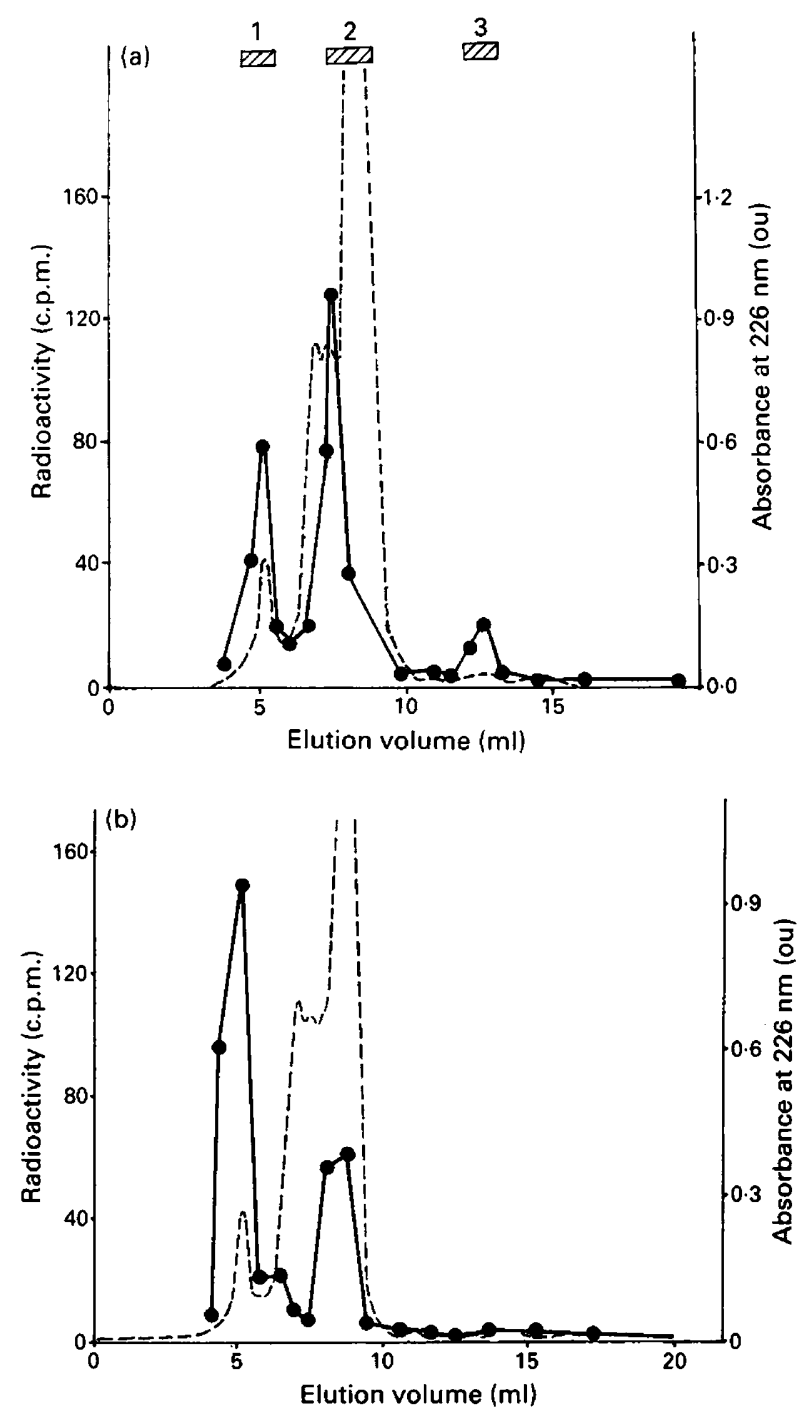

Fig. 3. (a) and (b).

\section{Proacrosin-to-acrosin converting activity in cumulus-oophorus secretion}

Medium after cumulus culture containing material released by liquefaction of the cumulusoophorus intercellular matrix significantly accelerated conversion of proacrosin to acrosin. The amount of proacrosin-converting activity in the medium accelerated the activation of $0.8 \pm 0.2 \mathrm{U}$ proacrosin. The amount of proacrosin activator was dependent on the amount of cumulus cells in the culture. Control medium did not exhibit this activity.

After medium separation on the TSK G-3000 SW column, a peak of proteins eluted in the void-volume region displayed activity of conversion of proacrosin to acrosin (Fig. 3a). The peak was absent in the elution diagram for control medium (not shown). The activity was eluted in the void volume also on a Separon HEMA S- 1000 column (not shown). It was hence inferred that the $M_{\mathrm{r}}$ of the proacrosin activator is at least $1.7 \times 10^{6}$. 


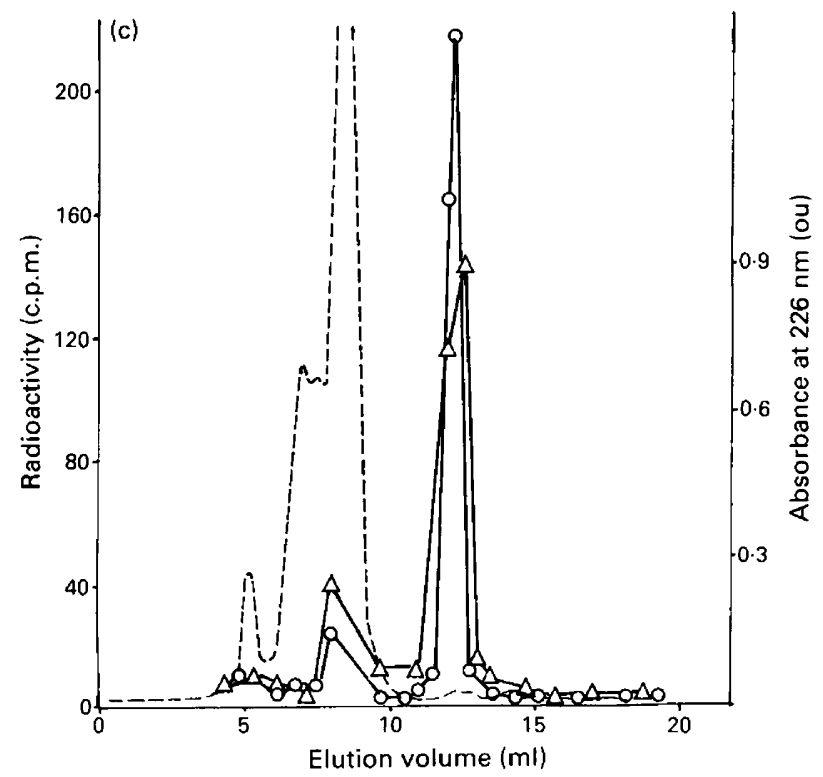

Fig. 3. (c).

Fig. 3. TSK G-3000 SW column elution diagrams of labelled human cumulus intercellular matrix liquefied by sperm hyaluronidase: radioactivity (-) absorbance in optical units (ou) at $226 \mathrm{~nm}(--)$. Material labelled with: (a) $\left[{ }^{14} \mathrm{C}\right]$ amino acid mixture $(\bullet)$, pooled fractions (छ); (b) $\left[{ }^{35} \mathrm{~S}\right] \mathrm{Na}_{2} \mathrm{SO}_{4}$ without enzymatic treatment (O); (c) $\left[{ }^{35} \mathrm{~S}^{\circ} \mathrm{Na}_{2} \mathrm{SO}_{4}\right.$ after treatment with chondroitinase $\mathrm{ABC}(\mathrm{O})$ or chondroitinase $\mathrm{AC}(\triangle)$.

Table 1. Activity of conversion of proacrosin to acrosin (U) in pooled fractions after chromatography of human cumulus-oophorus culture media, containing solubilized cumulus extracellular matrix

\begin{tabular}{ccccc}
\hline & \multirow{2}{*}{$\begin{array}{c}\text { Volume } \\
(\mathrm{ml})\end{array}$} & $\begin{array}{c}\text { Without enzyme } \\
\text { fraction* }\end{array}$ & \multicolumn{2}{c}{ After digestion with chondroitinase } \\
\cline { 5 - 5 } & $1 \cdot 5$ & $48 \cdot 3 \pm 3 \cdot 9$ & $\mathrm{AC}$ & $\mathrm{ABC}$ \\
\hline 1 & $2 \cdot 0$ & $1 \cdot 2 \pm 0 \cdot 4$ & $0 \cdot 3 \pm 0 \cdot 1$ & $0 \cdot 4 \pm 0 \cdot 1$ \\
2 & $2 \cdot 0$ & $0 \cdot 6 \pm 0 \cdot 1$ & $0 \cdot 2 \pm 0 \cdot 3$ & $0 \cdot 7 \pm 0 \cdot 3$ \\
3 & & & $0 \cdot 7 \pm 0 \cdot 4$ \\
\hline
\end{tabular}

*See Fig. 3a.

Concentration of the proacrosin conversion accelerator is expressed in $\mathrm{U}$ of acrosin activity resulting after conversion measured on whole fraction volume.

Data are means \pm s.e.m.

\section{Treatment of cell-secreted sulphated glycosaminoglycans with chondroitinase $\mathrm{AC}$ or $\mathrm{ABC}$}

After separation of medium containing components of cumulus matrix labelled with ${ }^{35} \mathrm{~S}$ on the TSK G-3000 SW column (Fig. 3b), the major peak of radioactivity was eluted in void volume at $5.25-5.5 \mathrm{ml}$ and had activity of conversion of proacrosin to acrosin. The rest of the radioactivity, which eluted in the elution volume $(8 \mathrm{ml})$ characteristic for compounds with $M_{\mathrm{r}}$ of $70000-90000$, did not accelerate proacrosin conversion.

When this medium was treated with chondroitinase $\mathrm{ABC}$ or $\mathrm{AC}$, the elution volume of the dominant radioactivity peak amounted to $13-14 \mathrm{ml}$ under identical chromatographic conditions 
(Fig. 3c). Fractions from the separate chromatographies were combined according to radioactivity peaks. Presence of proacrosin activator was detected in all combined fractions (Table 1). A proacrosin-to-acrosin converting activity was not found in any fraction from the column effluent. The elution volume of the second radioactivity peak $(8 \mathrm{ml})$ remained unchanged after the treatment with chondroitinase.

\section{Discussion}

Some studies have suggested that glycosaminoglycan moieties of proteoglycans play an important role in fertilization by affecting sperm capacitation and the acrosome reaction (for review see Lenz et al., 1983), and the conversion of proacrosin to acrosin (Parrish et al., 1980). Cumulus cells are an important source supplying proteoglycans to extracellular matrices of the oocyte-cumulus complex, i.e. the zona pellucida and the cumulus intercellular matrix (Tesařík \& Kopečný, 1986). The oocyte-cumulus complexes used in this study were recovered from preovulatory follicles $2 \mathrm{~h}$ before the expected time of ovulation and the fluid aspirated from each follicle was added to the medium in which its cumulus was being labelled. In this way, continuity of synthesis and secretion by preovulatory human cumulus cells was apparently maintained in vitro, since all the intrafollicular humoral factors supposed to control cumulus expansion (for review see Salustri et al., 1985) were present throughout the labelling period and the regulation of cumulus-cell differentiation in vivo through signals passing from mural granulosa cells via cell-cell coupling seem to have been shut down during late preovulatory development (Tesařík \& Dvořák, 1982).

Human cumuli-oophori showed active incorporation of radiolabelled precursors into the proteins being synthesized by cumulus cells within $30 \mathrm{~min}$ of incubation, as revealed by autoradiography. Secretion of newly synthesized proteins took place as early as within the $2 \mathrm{~h}$ labelling period used in most experiments. The consistent scanning-electron-microscope autoradiographs of cumulus-oophorus incubated with $\left[{ }^{3} \mathrm{H}\right]$ leucine and $\left[{ }^{3} \mathrm{H}\right]$ glucosamine demonstrated the usual behaviour of the newly secreted proteins and glycosaminoglycans in terms of their relationship with the cumulus matrix.

Cumulus cell secretion obtained after incorporation of a $\left[{ }^{14} \mathrm{C}\right]$ amino acid mixture consisted of several protein groups differing in $M_{\mathrm{r}}$ as revealed by column liquid chromatography and SDS-PAGE. Analysis of the cumulus-oophorus secretion using SDS-PAGE under dissociative, but nonreducing, conditions disclosed the real spectrum of proteins secreted by cumulus cells at the time of fertilization (Fig. 2). Two of the five protein families contained components labelled with $\left[{ }^{14} \mathrm{C}\right]$ fucose. The results indicated that cumulus-oophorus cells secrete a series of proteins and glycoproteins; but little is known about the role of these compounds.

The high- $M_{\mathrm{r}}$ glycoproteins have been described as binding to intact human spermatozoa and to modulate sperm function (Tesaŕík et al., 1988b). The existence of human cumulus substances inducing the acrosome reaction was claimed by Tesařík (1985; Tesařík et al., 1988a). The present work expands the information on the molecular aspects of fertilization by reporting on a substance that significantly accelerates the conversion of proacrosin to acrosin. The activator produced by cumulus-oophorus cells is, by its size and activity, similar to the proteoglycan that induces conversion of proacrosin to acrosin, found in human follicular fluid (Drahorád et al., 1988). Information about the character of this compound was obtained by analysis of the spectrum of sulphated glycosaminoglycans. Under the given culture conditions $\left(\mathrm{SO}_{4}\right)^{2-}$ groups could be incorporated only by sulphated glycosaminoglycans. Three types of glycosaminoglycans are soluble in water: chondroitin sulphate, dermatan sulphate and heparan sulphate, which can be recognized by the action of highly specific enzymes, chondroitinases. Chondroitinase AC cleaves only chondroitin sulphate; chondroitinase $\mathrm{ABC}$ cleaves both chondroitin and dermatan sulphate; heparan sulphate remains unchanged. The shift of the radioactivity peak into the low- $M_{\mathrm{r}}$ elution volumes, by the action of one of these specific enzymes (chondroitinase $\mathrm{AC}$ ), was evidence that the 
predominant proteoglycan in the fraction displaying proacrosin-to-acrosin converting activity contained chondroitin sulphate in its molecule.

The production of a proacrosin activator by cells surrounding the oocyte suggests its direct involvement in the fertilization process. Acrosin, a trypsin-like proteinase in the sperm acrosome in its inactive zymogen form, is believed to play an important role in sperm penetration through the zona pellucida (for review see Dunbar \& Wohlgemuth, 1984). Conversion of the zymogen to the enzymatically active form takes place before fertilization and its acceleration could be important in the fertilization process.

Some recent results show that the acrosomal reaction proceeds after the spermatozoon has been bound to the zona pellucida (for review see Wassarmann, 1987). Since sperm-binding to the zona pellucida can be effected with the help of proacrosin/acrosin (Töpfer-Petersen \& Henschen, 1987) emerging on the sperm surface before the start of the acrosome reaction (Tesařik et al., 1988a), the question arises whether the activation of proacrosin by cumulus-oophorus cell secretion triggers the acrosome reaction. The role of the proacrosin activator could then be to select fertile spermatozoa. The whole mechanism could proceed as follows: (i) sperm cells come into contact with the proacrosin-to-acrosin conversion accelerator; and (ii) intact spermatozoa that have proacrosin buried within their acrosomes do not interact with the glycosaminoglycans provoking proacrosin conversion, whereas spermatozoa having their proacrosin/acrosin accessible on their acrosomal surface do so and undergo the acrosomal reaction. If only spermatozoa possessing an unreacted acrosome can pass through the cumulus mass, whereas acrosome-reacted sperm cells adhere to the cumulus surface (Yanagimachi \& Philips, 1984), intact sperm cells could be selected from among partially damaged gametes.

We wish to thank B. Černý, Institute of Nuclear Biology and Radiochemistry, Prague, for performing the radioactivity measurements; V. Kopečný, Research Institute of Animal Production, Prague, for performing the electronmicroscopy and J. Pácová, Pig Insemination Development Center, Rajhrad, for generously donating the boar semen.

\section{References}

Ball, G.D., Bellin, M.E., Ax, R.L. \& First, N.L. (1982) Glycosaminoglycans in bovine cumulus-oocyte complexes: morphology and chemistry. Mol. Cell Endocr. 28, 113-122.

Drahorád, J., Cechová, D. \& Tesaŕík, J. (1988) Activation of proacrosin by a locally produced component of human follicular fluid. J. Reprod. Fert. 83, 599-603.

Dunbar, B.S. \& Wohlgemuth, D.J. (1984) Structure and function of the mammalian zona pellucida, a unique extracellular matrix. Modern Cell Biol. 3, 77-111.

Eppig, J.J. (1979) FSH stimulates hyaluronic acid synthesis by oocyte cumulus cells complexes from mouse preovulatory follicles. Nature, Lond. 281, 483-484.

Jonáková, V., Vidimská, B., Urbanová, J. \& Pavlík, M. (1990) Isolation and partial characterization of boar proacrosin. Collect. Czech. Chem. Commun. 55, 846853.

Laemmli, U.K. (1970) Cleavage of structural proteins during the assembly of the head of bacteriophage T4. Nature, Lond. 227, 681-685.

Lenz, R.W., Bellin, M.E. \& Ax, R.L. (1983) Rabbit spermatozoa undergo an acrosome reaction in the presence of glycosaminoglycans. Gamete Res. 8, $11-19$.

Moss, D.W. (1983) Nomenclature and units in enzymology. In Methods of Enzyme Analysis, 3rd edn, vol.
I, pp. 7-14. Ed. H. U. Bergmeyer. Verlag Chemie, Weinheim.

Parrish, R.F., Wincek, T.J. \& Polakoski, K.L. (1980) Glycosaminoglycan stimulation of the in vitro conversion of boar proacrosin into acrosin. J. Androl. 1, 89-95.

Salustri, A., Petrungaro, S. \& Siracusa, G. (1985) Granulosa cells stimulate in vitro the expansion of isolated mouse cumuli oophori: involvement of prostaglandin E2. Biol. Reprod. 33, 229-231.

Tesařík, J. (1985) Comparison of acrosome reactioninducing activities of human cumulus oophorus, follicular fluid and ionophore A23187 in human sperm populations of proven fertilizing ability in vitro. J. Reprod. Fert. 74, 383-388.

Tesařík, J. \& Dvořák, M. (1982) Human cumulus oophorus preovulatory development. J. Ultrastruct. Res. 78, 60-72.

Tesařík, J. \& Kopečný, V. (1986) Late preovulatory synthesis of proteoglycans by the human oocyte and cumulus cells and their secretion into the oocyte-cumulus-complex extracellular matrices. Histochemistry 85, 523-528.

Tesařik, J., Kopečný, V. \& Dvořák, M. (1984) Selective binding of human cumulus cell-secreted glycoproteins to human spermatozoa during capacitation in vitro. Fert. Steril. 41, 919-925. 
Tesał́ik, J., Drahorád, J. \& Pưknicová, J. (1988a) Subcellular immunochemical localization of acrosin in human spermatozoa during the acrosome reaction and zona pellucida penetration. Fert. Steril. 50, 133-141.

Tesałík, J., Pilka, L., Drahorád, J. Cechová, D. \& Veselský, L. (1988b) The role of cumulus cell-secreted proteins in the development of human sperm fertilizing ability: implication in IVF. Hum. Reprod. 3, 129-132.
Töpfer-Petersen, E. \& Henschen, A. (1987) Acrosin shows zona and fucose binding, novel properties for a serine proteinase. FEBS Lett. 226, 38-42.

Wassarmann, P.M. (1987) Early events in mammalian fertilization. A. Rev. Cell Biol. 3, 109-142.

Yanagimachi, R. \& Philips, D.M. (1984) The status of acrosomal caps of hamster spermatozoa immediately before fertilization in vitro. Gamete Res. 9, 1-19.

Received 13 April 1990 